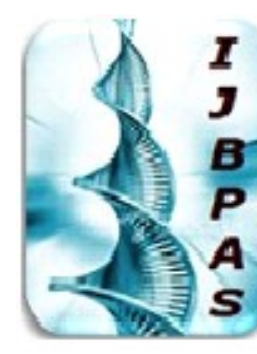

International Journal of Biology, Pharmacy and Allied Sciences (IJBPAS) 'A Bridge Betusen Caboratory and QRender' Www.iibpas,com

\title{
DETERMINATION OF CLOFARABINE BY UV VISIBLE SPECTROPHOMETER AND INFRA RED SPECTROSCOPY
}

\author{
SHIRMAN A ${ }^{1^{*}}$, INAMDAR ZE ${ }^{2}$, PATEL HY ${ }^{3}$, SHAIKH NS $^{4}$, MANYAR AI $^{5}$, SIDDIQI \\ HA $^{6}$, SHAHEENA $\mathrm{AS}^{7}$ \\ ${ }^{1}$ Department of Quality Assurance, Ali-Allana College of Pharmacy, Akkalkuwa Dist- \\ Nandurbar, Maharashtra, India \\ 2,3,4,5,6 Jamia College of Pharmacy, Akkalkuwa Dist- Nandurbar, Maharashtra, India \\ ${ }^{7}$ U.B.K.W.T.S D.pharmacy College, Kunjkheda, Dist-Auranagabad, Maharashtra, India \\ *Corresponding Author: E Mail: amshirman@gmail.com; Mob.No: +91-8128963764 \\ Received $8^{\text {th }}$ Dec. 2019; Revised $9^{\text {th }}$ Jan. 2020; Accepted 10 ${ }^{\text {th }}$ Feb. 2020; Available online $1^{\text {st }}$ Aug. 2020 \\ https://doi.org/10.31032/IJBPAS/2020/9.8.5131
}

\section{ABSTRACT}

HIV is a virus, when administered into the body it destroys T cells. HIV can be spread through Blood, Semen, vaginal and rectal fluids. Tenofovir is an anti-viral drug was determined by UV Visible Spectrophometer and Infra red Spectroscopy. For UV visible spectrophotometric study, Shimadzu 1800 double beam UV visible spectrophotometer, UV probes 2.33 was utilized. Tenofovir drug was identified by IR spectroscopy and also by Melting point determination and solubility.

Keywords: Tenofovir, UV Spectrophotometer, IR Spectroscopy, Determination

\section{INTRODUCTION}

Acute Lymphocytic Leukemia is cancer that affects the blood and bone marrow. The bone marrow makes white blood cells (WBC), red blood cells (RBC), and platelets [1-3]. WBCs help fight infection. RBCs help carry oxygen throughout the body. Platelets help the blood clot. ALL causes your body to make too many immature (young) white blood cells (WBC) [4-6]. These cells are cancer (leukemia) cells, and cannot fight 
infection like healthy WBCs. Cancer cells crowd the bone marrow and prevent it from making healthy blood cells. Without enough healthy blood cells, you are at risk for infection, bleeding, and anemia. Anemia is a low level of red blood cells. Clofarabine
(Chemically 5-(6-amino-2-chloro-purin-9-yl) -4-fluoro-2(hydroxymethyl)oxolan-3-ol) is a purine nucleoside antimetabolite that is being studied in the treatment of cancer [7-13] (Figure 1).<smiles>Nc1nc(Cl)nc2c1ncn2C1OC2CC(O)C1C2O</smiles>

Figure 1: Structure of Clofarabine

2. CHEMICALS, REAGENTS AND Standards, Reagents and instruments used in INSTRUMENTATION

Standards and Reagents: the study have been tabulated below in Table

1-5.

Table 1: Standard API Procurement

\begin{tabular}{|c|c|}
\hline Standard & Source \\
\hline Clofarabine & Yash Pharmaceuticals \\
\hline
\end{tabular}

Table 2: Sample Procurement

\begin{tabular}{|c|c|}
\hline Sample & Source \\
\hline Clolar infusion & Consilient Health Ltd \\
\hline
\end{tabular}

Table 3: Reagents Used In Experiment

\begin{tabular}{|c|c|c|}
\hline Chemical/ Reagent & Grade & Manufacturer \\
\hline Methanol & HPLC Grade & Finar \\
\hline Water & HPLC Grade & Finar \\
\hline Acetic Acid & AR & Spectrochem pvt Ltd. \\
\hline
\end{tabular}

Table 4: Instrumentation for UV spectrophotometer

\begin{tabular}{|c|c|}
\hline Component & Brand / Model / Software \\
\hline UV Visible spectrophotometer & Systronic 119 \\
\hline
\end{tabular}

Table 5: Instrumentation for Melting Range

\begin{tabular}{|c|c|}
\hline \multicolumn{2}{|c|}{ Table 5: Instrumentation for Melting Range } \\
\hline Component & Brand / Model / Software \\
\hline Melting point Apparatus & Analab \\
\hline
\end{tabular}

3. EXPERIMENTAL AND RESULT

\subsection{Identification of Drugs}

\subsubsection{Determination of Solubility}

Determination of Solubility is shown in Table 6.

\subsubsection{Determination of Melting Point:}


Determination of melting point is shown in

Table 7.

\subsubsection{Identification by IR:}

\section{(A) IR spectra of Clofarabine}

Figure 2 and Table 8 show the IR spectra of Clofarabine.

\subsubsection{Selection of wavelength}

The sensitivity of HPLC method that uses UV detection depends upon proper selection of detection wavelength. An ideal wavelength is the one that gives good response for the drugs that are to be detected.
In the present study drug solutions of Clofarabine $(20 \mu \mathrm{g} / \mathrm{ml})$ was prepared in Methanol. This drug solution was than scanned in UV region of $200-400 \mathrm{~nm}$ and maximum Absorbance was recorded.

Clofarabine solution: $10 \mathrm{mg}-\rightarrow 100 \mathrm{ml}$ with methanol. Further $1 \mathrm{ml}$ to a $10 \mathrm{ml}$ and make up with methanol $(20 \mu \mathrm{g} / \mathrm{ml}$ in methanol). Solutions was scanned between 200 - $400 \mathrm{~nm}$. Wavelength What Gives maximum Absorbance was selected from the Spectra (Figure 3).

Table 6: Determination of Solubility

\begin{tabular}{|l|l|}
\hline Drug & Solubility \\
\hline Clofarabine & Soluble in methanol and water \\
\hline \multicolumn{2}{|l}{} \\
\begin{tabular}{|l|l|}
\hline \multicolumn{2}{|l|}{ Table 7: Melting Point of Clofarabine } \\
\hline Drug & Melting Point \\
\hline Clofarabine & $221-224^{0} \mathrm{C}$ \\
\hline
\end{tabular}
\end{tabular}

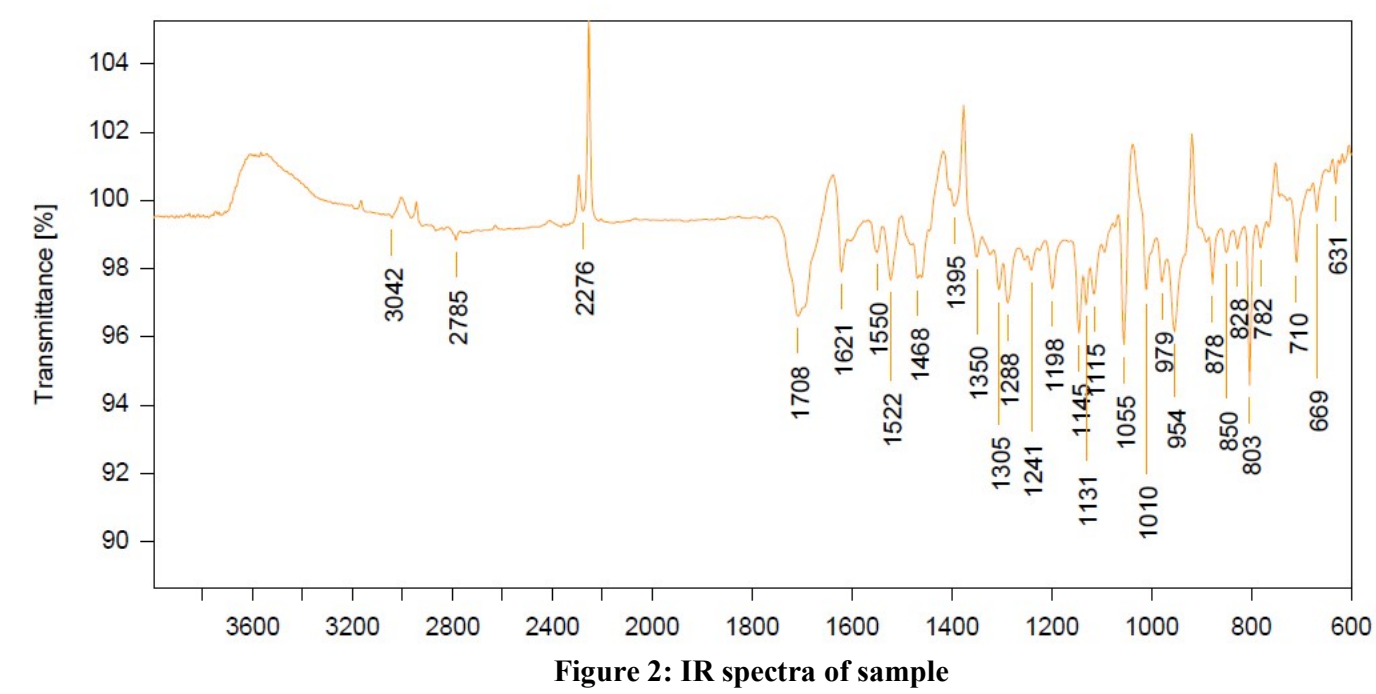

Table 8: Interpretation of IR of Clofarabine

\begin{tabular}{|c|c|}
\hline Frequency $\left(\mathrm{cm}^{-1}\right)$ & Assignment \\
\hline 710 & C-Cl (S) \\
\hline 1621 & N-H (S) \\
\hline 1288 & C-N (S) \\
\hline 2785 & O-H (S) \\
\hline
\end{tabular}




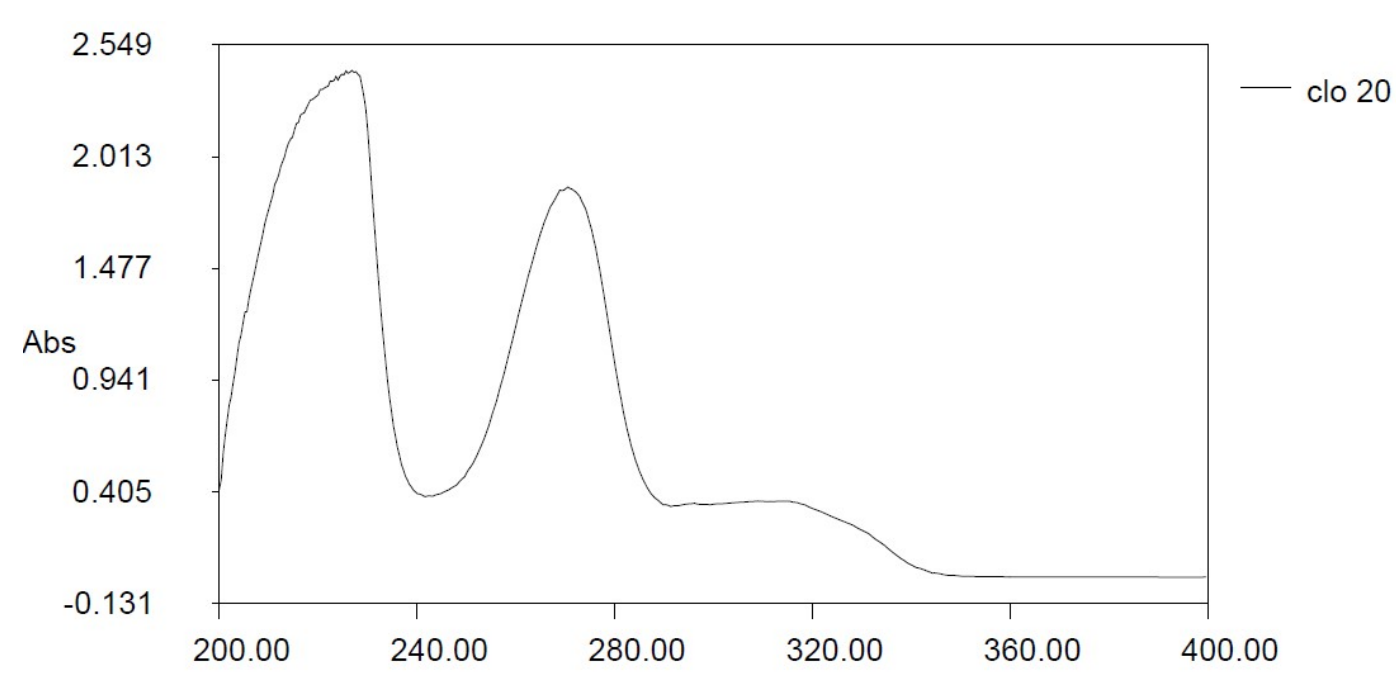

\section{CONCLUSION}

Figure 3: UV Spectra of Clofarabine (20 $\mu \mathrm{g} / \mathrm{ml})$ (Maximum Absorbance $254 \mathrm{~nm}$ )

Clofarabine is an Anti-neoplastic and anti-metabolite drug. Purpose of current research is to identify and determine the Clofarabine drug. Identification was carried out firstly by Infra-red spectroscopy, then determination of melting point and solubility of Clofarabine. Further, UV visible spectrophotometric study was carried out to optimise detection wavelength, which is beneficial for High performance liquid chromatographic study also. Hence, Clofarabine was scanned between 200-400 $\mathrm{nm}$ in UV Visible spectrophotometer.

\section{ACKNOWLEDGEMENT}

Authors are thankful to Management, Principals and Teaching \& Non-Teaching Staff of Jamia \& Ali-Allana college of Pharmacy, Akkalkuwa, Dist-Nandurbar, for their kind Support and motivation during research work.
6. REFERENCES

[1] "Introduction to Acute Lymphocytic Leukemia”, May-2017, https://www.drugs.com/cg/acutelymphocytic-leukemia.html

[2] Kasture AV., Mahadik KR., Wododkar SG and More HN "A Text Book of Pharmaceutical Analysis" $17^{\text {th }}$ Edition, Nirali Prakashan, Pune, 2002, pp. 48-57.

[3] Shethi PD,"HPLC-Quantitative Analysis of Pharmaceutical Formulations" CBS Publishers \& Distributers, New Delhi, 1996, pp. 3-46.

[4] Chatwal GR, "Instrumental Method of Chemical Analysis", Part-1, Himalaya Publishing House, 5th Edition, 2002, pp. 2.624-2.631.

[5] Rao JK, Murali SV, Malla RO: Validated Reverse Phase Stability-Indicating Hplc Method for Clofarabine in the Presence of Degradation Products and its Process- 
Related Impurities" J. Pharm. and Bio. Sci., 2016, 11(6) 63-72.

[6] FDA, "Guidance for Industry; Analytical Procedures and Methods Validation (Draft guidance), Food \& Drug Administration," Rockville, US Department of Health and Human Services, 2000.

[7] ICH, Validation of Analytical Procedures; Methodology, Q2 (R1), International Conference on Harmonization, IFPMA, Geneva 1996.

[8] Patel BD, Chhalotiya UK, Patel DB, "Quantification of Newer Anti-Cancer Drug Clofarabine in their Bulk and Pharmaceutical Dosage Form" J. Chrom. Sep. Tech., 2016, 1-4

[9] Satyanarayana L, Reddi S, "Development and application of Liquid Chromatographic method for determination of Clofarabine in bulk and in parentral dosage forms" Int. J. Res. trend and Inn., 2018, 3(3), 19-25

[10] Tandel JN, Patel JN, Shah SK, “ Quantification of Clofarabine and its impurity by RP-HPLC method in parental formulation" Int. J. Pharm. Sci. and Nano tech., 2017, 10(4), 37943804.

[11] Robinson JW, Skelly Frame EM and Frame GM, "Undergraduate
Instrymental Analysis", $6^{\text {th }}$ Edition, Marcel Dekker, 2005, pp 806.

[12] Ahuja S and Scypinski S, "Handbook of Modern Pharmaceutical Analysis", Academic Press 3, 2001 pp356-367.

[13] A Pession, R Masetti, K Kleinschmidt, and A Martoni, Use of clofarabine for acute childhood leukemia, BiologicsTargets and Therapy, 2010; 4: pp.111118. 